\title{
Bank Power and Public Policy since the Financial Crisis
}

\author{
Huw Macartney, University of Birmingham \\ David Howarth, University of Luxembourg \\ Scott James, King's College, University of London
}

Authors' pre-print; please reference as: Macartney, H., Howarth, D. and James, S. (2020) 'Bank

Power and Public Policy since the Financial Crisis', Business \& Politics, 22, 1, pp. 1-24,

doi:10.1017/bap.2019.35

\begin{abstract}
:
Despite much commentary in the media and the popular assumption that the banking industry exerts undue influence on government policy-making, the academic literature on the role of the banks since the 2008 financial crisis remains theoretically and empirically under-specified. In particular, we argue that different forms of financial power are often conflated, while favorable policy outcomes are too-readily assumed to be evidence of regulatory capture. In short, we still know relatively little about how bank influence varies over time and in different national contexts, the extent to which banking interests are unified or divided, and the conditions under which banks are capable of producing meaningful variation in policy outcomes. This article has three objectives: 1) to explain why the debate on bank influence matters; 2) to examine the evidence of bank influence since the international financial crisis; and 3) to set out a range of conceptual tools for thinking about bank power.
\end{abstract}

Keywords: banks, public policy, financial regulation, interest groups, financial crisis, regulatory capture

\section{Introduction: Why the debate on bank influence matters}

This special issue arose from a shared interest and concern about the influence of the largest banks in government policy making in western liberal democracies. The international financial crisis and the recent scandals concerning the fraudulent manipulation of interest rates by several banks in the United Kingdom (UK) and elsewhere have fuelled an intense debate about the "power" of the financial industry in the policy process. Despite much commentary in the media ${ }^{1}$ and the popular assumption that the banking industry exerts undue influence, ${ }^{2}$ the academic literature on the role of the banks since the crisis remains theoretically and empirically under-specified. In particular, we argue that different forms of financial power are often conflated, while favourable policy outcomes are too-readily assumed to be evidence of industry capture. In short, we still know relatively little about how bank influence varies over time and between different national contexts, the extent to which banking interests are unified or divided, and the conditions under which banks are capable of producing meaningful variation in policy outcomes. The aim of this special issue is to shed important new light on the role and influence of the banking industry over the past decade.

\footnotetext{
${ }^{1}$ See, for example, Wolf (2008); Wolf (2012).

${ }^{2}$ Cohan (2011); Johnson and Kwak (2010).
} 
This introduction has three objectives, around which the article is structured: 1) to explain why the debate on bank influence matters; 2) to examine the evidence of bank influence since the financial crisis; and 3) to set out a range of conceptual tools for thinking about bank power.

We argue that there are three main reasons to focus on bank influence on government policy making: one is the role that banks played in the lead up to the financial crisis; the second concerns the economic and social costs of the crisis; whilst the third concerns the theoretical claim that big firms have the potential to disrupt effective market competition and democratic politics. The first reason for our interest in bank influence is that we broadly subscribe to the view that banks played a major role in causing the 2007-08 financial crisis. The most immediate objection to this claim is that whilst large banks may have disproportionately benefitted from the regulatory and macroeconomic conditions prior to the financial crisis, this benefit was fortuitous rather than deliberate. Instead we begin this contribution with the premise that the financial crisis of 2007-08 was not simply the product of failures in abstract economic ideas or technical regulatory rules. Many accounts of the crisis focus on inadequate risk management systems, accounting practices, or neoliberal doctrine that led regulators to pursue arms-length, light-touch approaches towards the largest financial institutions. ${ }^{3}$ Instead, other accounts - including those represented in this special issue - argue that greater attention needs to be paid to the influence of the banking industry. In particular, there is overwhelming evidence of insufficient isolation of political authorities charged with designing financial regulation from the companies they were meant to be regulating — notably banks. ${ }^{4}$

The conflicts of interest arising for politicians can be interpreted in a variety of ways: as a consequence of the revolving door between public and private institutions; ${ }^{5}$ the result of regulatory or intellectual capture, ${ }^{6}$ or stemming from the structural role played by financial institutions in advanced western economies. ${ }^{7}$ Regardless of these differences, what is clear, we argue, is that democratic and regulatory institutions and rules were distorted by the influence of banking interests. The (relative) autonomy of political authorities in relation to private corporations, that is required to promote healthy market competition under liberal capitalism, was undermined. One overarching aim of this special issue is therefore to examine whether the degree of bank influence has changed in the decade since the financial crisis.

A second reason why bank influence is an important topic for analysis is because of the massive costs of the financial crisis in a number of western liberal democracies. Some estimates suggest that combining the two components of the United States (US) administration's response to the crisis - those linked to fiscal policy and those related to financial market policies, such as TARP, bank stress tests, and quantitative easing - approximately \$1 trillion (or 7\% of US GDP) was spent on fiscal stimulus, and that the TARP alone had a headline price-tag of $\$ 700 \mathrm{bn} .{ }^{8}$ Beyond the US, OECD estimates point to a $3 \%$ of GDP loss in output across all OECD countries, although the median fall in output across the 19 OECD countries that were impacted directly by the banking

\footnotetext{
${ }^{3}$ Skidelsky (2009).

${ }^{4}$ See Johnson and Kwak (2010).

${ }^{5}$ Seabrooke and Tsingou (2009).

${ }^{6}$ Stigler (1971); Barth et al. (2012); Claessens et al. (2008).

${ }^{7}$ Ingham (1984).

${ }^{8}$ Blinder and Zandi (2010), 2.
} 
crisis is actually closer to $6 \% .{ }^{9}$ Back in the US, studies have concluded that this decline in GDP translates into a loss in lifetime earnings of around \$70,000 for every American citizen. ${ }^{10}$

In Europe, the initial costs were arguably lower but the malaise and economic slowdown prompted by the crisis of public finances exacerbated by the banking crisis has been longer and deeper. The cost of bailing out British banks was closer to $\$ 137 \mathrm{bn}$, much smaller than the US bailout packages. But one result of this was that British banks - and the British economy - was much slower to recover. ${ }^{11}$ The larger US bailouts that were imposed on the industry helped the banks - and the economy - recover faster. Nonetheless, the crisis in US public finances and slowed output brought about the worst decade in real wage growth in almost 210 years. ${ }^{12}$ Whilst throughout much of continental Europe the banking and eurozone sovereign debt crises and the collapse in output resulted in a number of pressing macro- and micro-economic difficulties: inter alia, increased public and private indebtedness; higher unemployment and depressed earnings; and a financial sector with an increasing cost of credit and hence less profitable investment projects to fund. ${ }^{13}$

These are the obvious, tangible costs of the international financial crisis. But we argue, thirdly, that there are also the outcomes - at least in part — of the overweening power of banks. This is a controversial claim that needs to be unpacked both empirically and conceptually. Empirically, a range of studies of the pre-crisis period support this conclusion. ${ }^{14}$ Conceptually however, our claim about bank influence implies that the financial crisis was not simply the result of a benign "business and investment cycle" within the economy. Instead, a wide variety of intellectual positions have emphasised the negative impact of the influence of large financial corporations on both democracy and the market mechanism. In fact, this emphasis is closer to the original liberal writings of Adam Smith on monopolies; the rent-seeking arguments of John Maynard Keynes; or the instrumentalism of Marxist approaches. The concern over the distortive impact of large firms is perhaps most aptly described by the German ordo-liberals. ${ }^{15}$

In the view of the ordo-liberals, "competition is indispensable as an instrument of social

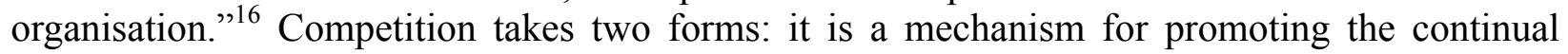
inducement of maximum performance on the part of both workers and capitalists; and it is a device for regulating and ordering the economic process, that is, governing supply and demand. ${ }^{17}$ Put differently, ordo-liberals were firm believers in the capacity of the unobstructed price mechanism to regulate among multifarious individual preferences. ${ }^{18}$ Yet competition was also a "category of disunity and strife, self-interest and greed, abuse and coercion."19 Managing the market economy

\footnotetext{
${ }^{9}$ Turner and Ollivaud (2019).

${ }^{10}$ BLS (2018).

${ }^{11}$ Macartney (2019), 170.

${ }^{12}$ Financial Times (2016).

13 Jimeno (2015), 6.

${ }^{14}$ For example, Engelen et al. (2012); Helleiner et al. (2010); Quaglia (2008); McKeen-Edwards and Porter (2013); Mügge (2010).

${ }^{15}$ Here we refer to the German economic tradition of ordo-liberalism associated with the Freiberg School in the $1920 \mathrm{~s}-30 \mathrm{~s}$, the ideas of which became synonymous with the 'social market economy'.

${ }^{16}$ Muller-Armack (1978), 326.

${ }^{17}$ Ropke (1957), 95.

${ }^{18}$ Muller-Armack (1978), 327.

${ }^{19}$ Bonefeld (2017), chapter 2.
} 
is therefore a matter for the state. Imposing order and rules is the function of government. "Changes in the law could make firms liable for some of the "disbenefits" they cause. Discrepancies between private costs and the spillover costs imposed on others can be corrected" by the state. ${ }^{20}$

In other words, large firms had both the incentive and the potential to disrupt the market mechanism by seeking special privileges from policymakers. They also sought to avoid bearing the costs associated with the adjustment to full competition. And the very means by which they would seek to shift these burdens onto other interest groups - both other firms and other elements of civil society - was via the state apparatus itself.

Put differently, we argue that two central features of countries that experienced the worst banking crises in 2007-08 are in large measure explained by the bank influence hypothesis: the fact that the largest US and EU-headquartered banks achieved favourable terms prior to the financial crisis was not fortuitous, but the result of their manipulation of the political process; and the fact these favourable conditions and the deferential approach of state managers helped to fuel - rather than rein in - the excessive behavior that culminated in financial instability. What the ordo-liberals described as the very function of the state - as market police - was thereby undermined by the "power" of the largest banks. This is why, in our estimation, the question of bank influence has very serious implications for our understanding of capitalism and democracy in the decade since the financial crisis.

\section{Evidence of bank influence since the financial crisis}

This special issue contributes to a growing literature examining the question of bank power since the financial crisis. ${ }^{21}$ In the second section we therefore briefly examine some of the evidence of post-crisis financial regulation over the last decade. The traditional method for analysing business power is through its impact on policy outcomes. ${ }^{22}$ In line with this, we argue that if our goal is to identify instances where the interests of the banks have substantively influenced policy-making and reform, the evidence is mixed. That is, there are various important examples of instances where banks proved to be unsuccessful; whilst there are other important successes.

Of course, using legislative and regulatory outcomes as a proxy for measuring bank influence leads to a very narrow focus that may itself be unhelpfully restrictive. But for now, suffice it to note that based on this measure there certainly appear to be a variety of instances of banks directing and limiting the reform process. Likewise, there also appear to strong examples of failure of the assertion of bank influence. We provide here a brief overview to support the claim that there have been both successes and failures in banks efforts to influence policy over the past decade, while the articles in this special issue provide more detail on some important examples.

Bank bonuses - and bankers' remuneration more generally — are an important case of bank influence because they proved to be one of the most contentious and politically salient issues

\footnotetext{
${ }^{20}$ Brittan (1989), 50.

${ }^{21}$ For example, Bell and Hindmoor (2015, 2017); Culpepper and Reinke (2014); Howarth and Quaglia (2013, 2016); James (2018); James and Quaglia (2020); Newman and Posner (2018); Pagliari and Young (2014); Woll (2014).

${ }^{22}$ Culpepper (2015).
} 
following the financial crisis. In the US, despite their inclusion in the original Dodd-Frank Act, five years later the Obama administration had failed to make any significant progress on reducing the overall level of bankers' remuneration. ${ }^{23}$ Instead, changes were limited to deferral — delaying the bonus - and revisions to the structure of the remuneration; both of which were intended to limit the short-termist tendencies. It was widely recognised that these relatively meagre reforms were a direct product of successful bank lobbying. ${ }^{24}$ On the other hand, in Europe, the bonus cap directly challenged the preferences of the larger banks by imposing a limit on the actual level of the pay-out itself. ${ }^{25}$

But this difference in remuneration policy adopted should not be read as simply indicative of either a lighter-touch approach by US authorities or successes of the US banking lobby in all areas. In the area of bank structural reform for example, a central feature of the Dodd Frank act was the socalled Volcker rule which prohibited proprietary trading — trading with their own capital solely for their own profit - for US banks. This was also a significant and contentious issue because it also placed much stricter requirements and a higher burden of proof on US banks' other "marketmaking" - customer-serving — trading activity. On the other hand, attempts at similar panEuropean reforms in the shape of the Liikanen proposals were effectively vetoed by a coalition of the largest banks and national authorities. ${ }^{26}$

Tough financial penalties imposed on the largest banks are a third example of a highly contentious and politically salient response by, in particular, US and UK authorities. Several accounts point to the fines as evidence of a stricter, more nationalistic approach by US state managers towards both their domestic and foreign banks. ${ }^{27}$ Yet other recent accounts have challenged this, arguing that bank lobbying influenced the terms of the penalties so that they were much less punitive in reality that they might have appeared at face value. ${ }^{28}$ As with many examples of post-crisis measures, the devil is often in the detail; and it would appear that banks lobbied quite effectively for more lenient terms attached to the fines.

Major new pieces of European and international regulation such as MiFID II and Basel III also appear to have been motivated by a much stricter political approach to banks. MiFID II imposes significant constraints on research and fees structures for banks as well as demanding that certain types of activity be conducted on more transparent limit-order or electronic exchanges; these changes arguably undermine important and lucrative banking strategies in areas such as corporate bond trading and fixed income activities. Similar conclusions have been drawn concerning Basel III and the limits placed on banks' inventory of bonds so that the new legislation poses a significant threat to the business models of the largest global banks. ${ }^{29}$ On the other hand, some accounts have argued that the more recent dilution of Basel's trading book requirements and the watering down of capital requirements in the EU context provide evidence of renewed back to power and influence. $^{30}$

\footnotetext{
${ }^{23}$ Wall Street Journal (2017)

${ }^{24}$ Zeigler and Woolley (2016).

${ }^{25}$ Andrés et al. (2019).

${ }^{26}$ Howarth and James (2020), Hardie and Macartney (2016).

${ }^{27}$ Emmenegger (2015).

${ }^{28}$ Macartney and Calcagno (2019); Campbell-Verduyn (2017).

${ }^{29}$ Howarth and Quaglia (2013)

${ }^{30}$ Howarth and Quaglia (2016).
} 
Finally, in other jurisdictions, the evidence of political support for new challenger banks and fintech firms arguably also suggests an existential threat to more established banks. In the UK, for example, the Treasury and the Competition and Markets Authority turned to fintech and Open Banking to resolve the investment gap and improve output in the real economy. The view of the Conservative-led government was that the larger established banks were failing in their role of lending to small and medium sized enterprises - the lifeblood of the economy. Fintech firms in the shape of Peer-to-Peer lenders and digital-led challenger banks - were perceived to be the solution. The result was a massive increase in new banking licenses and an increase in market share for these alternative lending platforms. In other European countries though, as Massoc argues, ${ }^{31}$ policymakers chose to defend their largest banks against the threat of greater domestic competition.

What conclusions are we to draw from this brief overview of the post-crisis reform record? Put simply, it appears that on some occasions banks achieved their desired policy outcomes whilst on other occasions they did not. At this general level of analysis the evidence is however, extremely opaque. Inter- and intra-national, as well as intra-industry differences are unclear. Banks in one national or regional jurisdiction clearly did not want the same policy outcome; nor did policymakers. What then were the mechanisms determining the successes and failures of bank influence? The understanding of competing preferences and the mechanisms through which bank influence was assured or reduced requires close empirical investigation. Such investigations are shaped however - more or less explicitly - by conceptualizations of how capitalism and democracy, firms and governments, and ideas and institutions interact. This leads us to the third objective of this contribution.

\section{Conceptualizing bank power}

Our aim in this section of the paper is to embed the discussions about bank power in a series of conceptual debates about the power and influence of businesses more broadly and banks in particular. As above, these conceptual debates are intended to provide some basis for answering the question as to why the record of bank influence since the international financial crisis has been so mixed. In particular, we aim to provide various ways of understanding the power of banks in shaping public policy outcomes in the past decade.

With their origins in the work of Lindblom and Block, theories of business power suggest that corporate influence comes from two main sources: ${ }^{32}$ one is the direct, instrumental power of firms; the other focuses on the structural power they possess. Direct, relational power refers to those "non-core functions of the firm on which business relies to attain a political edge", such as campaign donations or lobbying. ${ }^{33}$ Structural power refers to the fact that business control the investment decisions on which the economy depends for growth. ${ }^{34}$ Variation in business power

\footnotetext{
${ }^{31}$ Massoc (2020).

${ }^{32}$ Lindblom (1977); Block (1987).

${ }^{33}$ Culpepper (2015), 396.

${ }^{34}$ See Quinn and Shapiro (1991); Swank (1992); Przeworksi and Wallerstein (1988).
} 
over time and place derives from how these critical sources of power are mediated by both institutions and ideas. ${ }^{35}$ We review this literature in the following four subsections.

\section{Banks are not a privileged group}

On the first, the most substantive criticism of business power in general, and bank power more specifically, is that they do not in fact hold a privileged position. This line of criticism is a direct response to the structural view. It springs from a number of observations: the first is that structural theories fail to account for the ubiquitous nature of business lobbying. If policymakers are so readily willing to adjust policies to suit business interests, why do businesses invest so much time and money in lobbying? ${ }^{36}$ The second criticism is that businesses do not always win. ${ }^{37}$ Often policy reform directly conflicts with the interest of business groups. ${ }^{38}$ One conclusion is, therefore, that business is an interest group like any other, neither inherently advantaged or disadvantaged in pursuing its interests. Criticisms have also focused on how we measure business influence: one of the main criticisms of structural approaches is that unless we use policy outcomes as a measure of the success or failure - the influence - of business, it is hard to trace the causal effect of structural power. Furthermore, since policy outcomes remain the main metric - dependent variable available to political scientists, the ability to distinguish between the causal effect of structural and instrumental power is limited by problems of observational equivalence.

In relation to our puzzle about the apparent successes and failures of bank lobbying, the answer from this perspective is therefore relatively straightforward: accounts that emphasise the nonprivileged position of business argue that there have been successes and failures because this is what we would expect to find. Banks are simply an interest group like any other. Although banks may be well-resourced, the nature of policy-making in pluralist democracies would indicate that compromises are the most likely outcome as their interests must be balanced against those of other (often latent) groups, such as consumers and taxpayers.

\section{Banks were temporarily disoriented}

Secondly, in direct contrast to the previous pluralist account are a range of arguments emphasising the structural power of business in general and, in our case, the banks. As Dahl and Lindblom argued, "common interpretations that depict the American or any other market-oriented system as a competition among interest groups are seriously in error for their failure to take account of the distinctive privileged position of businessmen in politics." "39 According to Marsh and Lewis: "for Lindblom, a, perhaps the, major role of government is to encourage businessmen to invest and produce; thus increasing GDP and improving everyone's standard of living." ${ }^{40}$ This gives business a structural power, with a coercive and ideological dimension, because governments must "anticipate and defer" to business demands. ${ }^{41}$

\footnotetext{
${ }^{35}$ For example, see Culpepper (2015) and Bell and Hindmoor $(2015,2017)$.

${ }^{36}$ Smith (2000).

${ }^{37}$ Vogel (1989).

${ }^{38}$ Bernhagen (2007).

${ }^{39}$ Dahl and Lindblom (1976), xxxvi.

${ }^{40}$ Marsh and Lewis (2014), 628.

${ }^{41}$ Lindblom (1982), 325; see also Hall (1986); Quinn and Shapiro (1991); Swank (1992); Andrews (1994); Przeworksi and Wallerstein (1988); Strange (1998).
} 
In relation to our problematique, the argument is that the largest banks do indeed possess a structural power, but that - in answer to the question of bank success or failure - this power has waxed and waned over the past decade. The US and most EU national banking systems have been in a state of flux for a number of years. Here we briefly outline two interrelated considerations which may have affected banks' structural power: the macroeconomic environment; and the "real" source of bank power.

Quite aside from the impact of political and regulatory initiatives, the macroeconomic environment of the past decade has had a significant impact on the revenue and profit margins and operations of the largest banks. In particular, the profitability of specific business strategies and the overall firm has shown considerable variation. Loose monetary policy - low interest rates and Quantitative Easing in the US, UK and eurozone - has played a particularly significant role. The orthodox view of the monetary policy transmission mechanism suggests that this accommodative (so-called "extraordinary") monetary policy should translate into increased bank lending to the economy. Yet it is also widely recognised that loose monetary policy has historically been one of the main drivers of non-interest income in the banks, precisely because it places downward pressures on revenue from traditional (interest-based) lending activities. As Haldane et al. conclude, low yields on safe assets and slow returns from sluggish economic recovery, combined with excess liquidity — provided by accommodative monetary policy — "encouraged investors to put money into riskier asset classes." ${ }^{42}$ In other words, bank business models have been challenged and have been in a state of flux, partly as a result of macroeconomic conditions.

Furthermore, loose monetary policy has also decimated other areas of profitability for the largest banks, and left them in a vulnerable competitive position in relation to asset management firms and newer fintechs. For example, in the area of corporate bond trading, business that was previously dominated by the largest dealer-banks, loose monetary policy appears to have disempowered the banks. Low interest rates led to a glut of new corporate borrowing. But lower interest rates have also meant lower returns on the debt provided by the banks in the corporate bond markets. This is because when interest rates fall, for example, older bonds become more valuable because they were sold in a higher interest rate environment and hence have higher coupons. ${ }^{43}$ Looser monetary policy would therefore traditionally have required (and actively encouraged) Wall Street dealer-banks to take additional risks in corporate bond markets. As we noted above though, as a result of new Basel III trading book rules and the Volcker clause in DoddFrank, banks were limited in their capacity to hold large inventories of bonds. Instead, newer fintech firms gained market share - at the expense of the larger established banks - because of their ability to price and execute more competitively than the regulation-affected banks.

The macroeconomic environment has therefore been an important factor explaining the profitability or weakness of particular banks and banking systems. Here there are noticeable differences between the impact upon European and North American banks. Whilst the trend for European banks has been towards slow progress and downsizing, Wall Street banks have grown and expanded significantly in the aftermath of the financial crisis. Indeed, the conclusion of some commentators was that by 2018 Wall Street banks had established a "seemingly unshakeable

\footnotetext{
${ }^{42}$ Haldane et al. (2016), 8.

${ }^{43}$ PIMCO (2018).
} 
dominance in global corporate and investment banking." 44 Cost-cutting and more conservative risk-taking initially characterised the Wall Street response - as was the case in Europe: in 200810 the aim was "to reduce the balance sheet and simplify the organisation;" 45 a "smaller and more humble financial services industry" 46 was the message. But by 2015 a combination of an upturn in the credit cycle and US economic recovery had led to heightened credit risk ${ }^{47}$ and a return to riskier asset classes.

These macroeconomic conditions might go some way to explaining the mixed record of bank influence over the last decade. Banks struggling to adapt and streamline may have found it increasingly challenging to exert themselves in the political domain. If this is the case, greater sensitivity to the conditions affecting banks might serve to vindicate the structural power view of some academics.

We imply above that the macroeconomic environment placed many banks on the back foot. This would certainly go some way to explain bank losses and failures to exert influence over the last decade. But what of the successes? What does the structural account have to offer here? Simply put, the argument of some approaches to bank power is that banks still possess a structural influence that is also not just reducible to their role as credit or investment providers. It goes without saying that banks are not the only — or even perhaps the most important - firms that lend to the domestic economy. This is why the question of the sources of bank influence is crucial. As Vogel argued, the "sources of business strength are either exclusively or disproportionately available to capitalists;" 48 but these sources are not limited to investment decisions.

Arguably, the main source of bank power as the financial crisis hit stemmed from their Too Big To Fail (TBTF) status. This, in turn, had its origins in the system of deposit guarantees afforded large universal banks. ${ }^{49}$ Government protection comes in three forms: liquidity insurance (protecting wholesale deposits), deposit insurance (protecting retail deposits), and capital insurance (protecting shareholder equity). ${ }^{50}$ Liquidity insurance dates back to the early nineteenth century, but deposit insurance and capital insurance have a shorter history, emerging after the great depression. $^{51}$ They were initially put to the test in 1982, when one of the largest American commercial lenders, Continental Illinois National bank and trust Company (CINB) collapsed and was subsequently bailed out, with US regulators significantly expanding the customer deposits they were willing to insure. The ensuing debate centred on whether large banks had to be treated differently to smaller institutions. ${ }^{52}$ The decision was made that they should be. But the result not only boosted the share prices - of the largest firms because of their implicit guarantee — but also reduced their funding costs, giving them a significant competitive advantage. ${ }^{53}$ The point is that

\footnotetext{
${ }^{44}$ Financial Times (2018).

${ }^{45}$ Citigroup (2008), 8.

${ }^{46}$ Bank of America (2008), 3.

${ }^{47}$ OCC (2016), 3.

${ }^{48}$ Vogel (1996), 300.

${ }^{49}$ Steern and Feldman (2004), 11.

${ }^{50}$ Alessandri and Haldane (2009), 3.

${ }^{51}$ Macartney (2019), 39.

${ }^{52}$ FDIC (1987), 112.

${ }^{53}$ Alessandri and Haldane (2010).
} 
the expectation of state support has been shown to make share and bond prices, as well as the cost of debt for these largest banks, less sensitive to risk. ${ }^{54}$

These details are vitally important for two reasons. First, despite the significant changes to bailout structures and the new or revised resolution regimes adopted in the US and EU designed to allow banks to be closed down, it is not at all clear that this source of bank power - size - and the competitive advantage it affords them has been resolved. This also means, secondly, that although political authorities have made various attempts either to promote greater competition in the provision of investment/credit or drive forward measures like the EU Capital Markets Union to diversify and deepen financial markets ${ }^{55}$ — intended, in part, to decrease real economy reliance upon the largest banks - these same banks arguably continue to hold their TBTF status combined, in many instances, with that of national champion. According to some accounts, the sources of financial power - the advantages of the largest banks - are arguably disproportionate and significantly different from the sources of power in other industries. Put differently, it is not sufficient to dismiss the structural argument on the basis of doubts about the "threat of disinvestment;" bank structural power might emanate from a range of other sources, such as TBTF, which continue to exert an influence on democratic politics.

Banks may also assert structural power in more subtle ways. For an incumbent government, the prospect of certain types of private investment - and the potential threat of disinvestment - rely not on explicit threats, but more on the perceptions of policy makers and the discursive construction of business "power" by industry lobbyists. ${ }^{56}$ In this sense, an important source of structural power for banks may be the inherently uncertain and unpredictable quality of financial markets, which serves as a powerful constraint on regulators' scope of action. In a novel contribution to this special issue, Bart Stellinga argues that it is indeed the complex and "reflexive" qualities of financial markets that have hampered key post-crisis reforms: notably, the implementation of macroprudential policies aimed at mitigating systemic risks..$^{57}$ In particular, he suggests that the weakness of macroprudential policy recommendations in international and EU level fora owes to the inherent difficulties facing regulatory authorities in seeking to identify and measure the build-up of systemic risk. Therefore, the intractability of systemic risk - and not bank influence per se - significantly weakened the capacity of regulators to change bank behaviour.

\section{The mediating role of ideas and institutions}

A third range of academic explanations for the success or failure of back efforts to influence government policy emphasize how business power is mediated by ideas and institutions. This adds a further dimension to both the structural and the instrumental explanations of bank influence by emphasising the particular political dynamics within which banks have sought to exercise their influence. To misuse Mark Blyth's adage, economic events and processes do not come with an

\footnotetext{
${ }^{54}$ Lindh and Schich (2012), Hau et al. (2013), O’Hara and Shaw (1990), Morgan and Stiroh (2005), Balasubramnian and Cyree (2011), Acharya et al. (2014).

${ }^{55}$ Quaglia and Howarth (2018).

${ }^{56}$ Hay and Rosamond (2002).

${ }^{57}$ Stellinga (2020); see also Stellinga and Mügge (2017).
} 
instruction manual: ${ }^{58}$ they are interpreted and narrated; and this relies on both the inter-subjective understandings of political elites and the competing narratives of particular interest groups. ${ }^{59}$

Culpepper develops this line of thought more systematically, by emphasising issue salience and institutional governance as two vital factors that shape the effectiveness of business agency. ${ }^{60}$ When issues are off the public radar (low salience) business can rely on the "quiet politics" of access to government. Here government is more likely to defer to corporate interests because nonbusiness groups are less active and the issues themselves can be delegated to more informal institutions. On the other hand, as salience increases, non-business groups become more active, seeking to challenge business influence; as a result, governments are often forced to escalate issues to more visible and transparent arenas in order to secure greater legitimation. ${ }^{61}$ In his article for this special issue, Giuseppe Montalbano argues that, at the agenda-setting stage, large financial institutions - notably banks - established a policy coalition with the European Central Bank, the Bank of England, and the EU Commission which proved to be relatively effective. However, as the political saliency of reforms increased further into the legislative process, the financial industry coalition proved to be slightly less effective. A focus on salience more generally has the benefit of overcoming some of the criticisms of structural versus instrumental accounts. Culpepper and Reinke argue that the sources of business power (structural versus instrumental) are not the only decisive variables, ${ }^{62}$ how these resources are mobilised (automatically or strategically) is also very significant. In this way, we can see that structural power often has to be asserted strategically in order to be effective in a specific policy domain.

This supports the findings of David Howarth and Scott James who, in their article for this special issue, argue that the reason for the UK Conservative-led government pursuing the toughest bank structural reforms - ring-fencing - in Europe despite the Conservative party's traditionally deferential approach towards the City and the largest banks was a matter of political timing. ${ }^{63}$ The right confluence of ideas, institutions, popular pressure, and activities of the banks in question gave rise to a stringent set of reforms. Other studies also highlight the strengthening of state capacity and powerful ideational narratives as factors that have curtailed the instrumental influence of financial lobbyists ${ }^{64}$ and limited the credibility of threats to disinvest from a particular country. ${ }^{65}$ In his article for this special issue, Mehmet Kerem Coban argues that the strength of the Turkish regulator - its regulatory capacity — was significantly greater than the banking sector's "capture capacity." Both banks and regulators in Turkey faced pressures to be seen to be complying with international standards; but bankers were much more sceptical as to Basel III requirements, arguing that they were too restrictive for a developing country like Turkey. Yet regulatory authorities succeeded in limiting bank influence through a policy-making process that restricts private sector access. Furthermore, in her article for this special issue, Elsa Massoc argues that the important explanatory factor of very different bank structural reforms adopted in the UK, France and German

\footnotetext{
${ }^{58}$ Blyth (2002).

${ }^{59}$ Van Apeldoorn (2002).

${ }^{60}$ Culpepper (2012).

${ }^{61}$ Culpepper (2012), 180-181.

${ }^{62}$ Culpepper and Reinke (2014).

${ }^{63}$ Howarth and James (2020).

${ }^{64}$ Woll (2014); Bell and Hindmoor (2017); Culpepper and Reinke (2014).

${ }^{65}$ James (2018); James and Quaglia (2018).

${ }^{66}$ Coban (2020).
} 
was not the relative strength or weakness of the banking lobby in the three countries. ${ }^{67}$ Rather, she emphasizes the relative power of anti-Too-Big-To-Fail factions in domestic politics and the institutional capacity of agents that were less deferential to the large banks to influence the policymaking process.

Other papers in this special issue speak to the important mediating role of political institutions. In his contribution, Jo Ganderson focuses upon the relevance of institutional democratic variables and notably majoritarian versus consensus party systems - in shaping the influence of banks over government policymaking on financial regulation. ${ }^{68}$ In particular, he argues that structural separation of banks in the UK was a product of adversarial party competition which challenged the power of industry; by contrast, the dynamics of power sharing and consensus in the Netherlands enabled the bank lobby to redirect reform efforts towards less threatening initiatives targeting bank culture. The article by David Coen and John-Paul Salter point to additional institutional features to explain the relationship of banks and regulatory agencies. ${ }^{69}$ They argue that the decision of banks to forge a close relationship with a particular regulatory agency depends on three factors: the agency's credibility, its legitimacy, and its transparency. They conclude that the connections between the European Banking Authority (EBA) and banks are still in their infancy and that banks have been discouraged to improve relations because of the EBA's problematic legitimacy especially in comparison with a number of national authorities — and lack of transparency.

Beyond the specific contributions to this special issue, the ideational-institutional account also highlights that waning political willpower and a change of government can also work to reempower banks or limiting the reform agenda. The dismissal of Martin Wheatley — the vocal critic of the banks who lead the UK Financial Conduct Authority — is a case in point. His departure was emblematic of the new Conservative government's softer approach to the City in 2016. Similarly, Richard Cordray, the hard-line head of the US Consumer Financial Protection Bureau, resigned in response to the more lenient approach of the Trump administration regarding banks. ${ }^{70}$ Indeed, the Trump administration brought with it promises of relaxing the more stringent parts of the US Dodd Frank Wall Street Reform and Consumer Protection Act. ${ }^{71}$ Further, in its first months, the Trump Presidency appointed former Goldman Sachs grandees to assist the more sympathetic approach towards banks. At any rate, both the successes and failures of the banks can be explained with reference to the ideas and institutions within which political struggles have occurred.

\section{Banks are not unified}

The fourth explanation for the successes and failures of the banking sector since the financial crisis is that the cohesiveness and homogeneity of bank lobbying should not be taken for granted. Individual national case studies had earlier cautioned against overemphasising the unity of corporations in influencing government policy. ${ }^{72}$ In the UK, for example, it was widely recognised that small businesses had struggled to act collectively; historically this was in sharp contrast with financial trade associations and the banking sector in the UK. ${ }^{73}$ But more recent studies have also

\footnotetext{
${ }^{67}$ Massoc (2020).

${ }^{68}$ Ganderson (2020).

${ }^{69}$ Coen and Salter (2020).

${ }^{70}$ Washington Post (2018).

${ }^{71}$ New York Times (2018).

${ }^{72}$ Nettl (1965).

${ }^{73}$ Moran (2009).
} 
problematized cohesion among different elements of the financial sector. ${ }^{74}$ In other words, "sharp divisions... among different parts of the private finance sector" can have significant detrimental effects on their lobbying power. ${ }^{75}$ In their article for this special issue, Howarth and James point to major divisions in national banking sectors as one factor explaining the weakness of bank influence in the UK on structural reform. ${ }^{76}$ Furthermore, in his article, Giuseppe Montalbano points to alliances between specific large banks and other supportive financial firms seeking to encourage the EU's efforts to promote securitization half a decade after the financial crisis had sorely damaged the reputation of this financial technique. ${ }^{77}$

These accounts depart from the a priori assumption that large global banks, even those sharing the same home country, have shared preferences. Instead, the assumption is that preferences are more likely to diverge, which poses problems for exerting influence over government policy. Some of these accounts - including the article for this special issue by Adam Chalmers and Kevin Young - emphasise "socialization networks" that form between industry actors and how shared preferences emerge from the proximity of these relationships between private firms. ${ }^{78}$ The conclusion, with regard to our puzzle about the successes and failures of bank efforts to influence government policy in the aftermath of the financial crisis, would be that financial actors were more likely to be successful when they had closer, network-like, connections with other financial agents. These networks would in turn have promoted a convergence of interests and also the potential to act collectively in a more assertive way. Chalmers and Young find evidence that organizations' preferences are informed by their location within socialization networks. Controlling for a range of other plausible factors, the authors find that those connected via common associational ties, those closer to one another in the network and those more "embedded" in this network are all less likely to diverge in terms of their preferences from one another.

\section{Critical approaches to the state}

Returning to our central question about how to explain the mixed record of the banking industry in shaping government policy since the financial crisis, a fifth set of "critical political economy" accounts depart from some of the institutionalist and rationalist assumptions mapped out above. Instead they have their origins in the Marxist accounts of Poulantzas, Offe, and Habermas. Rather than emphasising either the instrumental (lobbying) power of capital (corporations), or verging on the equally problematic Marxist version of structuralism - that business almost always gets its way because the state is simply the executive committee of the capitalist class - these accounts argue that there is nonetheless a structural bias within the state. ${ }^{79}$ The result is that the state is not in itself a neutral instance, but is preoccupied with reconciling two often contradictory priorities: securing the conditions for sustainable accumulation and maintaining the legitimacy of the particular capitalist order. ${ }^{80}$

These "critical political economy" accounts may have certain merits when applied to the bank power debate following the financial crisis. In particular, they help to make sense of the apparent

\footnotetext{
${ }^{74}$ Young and Pagliari (2017).

${ }^{75}$ Helleiner and Pagliari (2011), 179.

${ }^{76}$ Howarth and James (2020).

${ }^{77}$ Montalbano (2020).

${ }^{78}$ Chalmers and Young (2020). See also James and Christopoulos (2018); Tsingou (2015).

${ }^{79}$ Offe (1972); Streeck (2014).

${ }^{80}$ Gamble 2009; Burnham (2011).
} 
conflict between the rhetoric and the reality of a variety of reforms. In many areas — inter alia, the financial penalties imposed upon banks, bank levies, lending targets, and the public interrogation of bankers by state authorities - the political rhetoric of elected politicians and financial regulators depicted an attempt to punish banks and promote a new social contract between banks and civil society (Macartney 2014). In reality though, these measures fell a long way short and were often disturbingly light-touch. In contrast to some of the accounts summarised above, the weakness of these measures may not only have been due to effective bank lobbying or of structural threats of bank disinvestment. Rather this weakness may reflect an attempt by state managers to deflect criticism and restore credibility (legitimacy) without significantly undermining the particular (financialised) variety of capitalism in their respective jurisdictions. ${ }^{81}$

At the very least, we would argue that if our goal is to ascertain the winners and losers of bank reform since 2008, it is important not to dismiss a range of approaches which tackle this question from an alternative conceptual point of entry.

\section{Conclusion}

This introduction has been framed by three objectives. First, we seek to explain why — at both a concrete and abstract level - the study of bank influence in western capitalism is extremely important. The debates on the relationship between capitalism and democracy have been extensively covered and have a long history. But the costs of the financial crisis and the evidence of the overweening power of banks encourages fresh examination of this relationship. Our second objective is to examine the empirical record since the financial crisis. The range of financial reforms is vast. Here we provide a brief overview to support the claim that despite the fact that post-crisis reforms were ostensibly intended to rein in the excessive influence and instability of the banks, there is also evidence of banks benefitting from and watering down reforms. As the articles in this special issue show, there has been significant variation in bank influence over time and place. Then, third, we set out a range of conceptual tools to explore the successes and failures of the banking industry to shape policy since the crisis. Here we integrate some longstanding debates about business power, with more contemporary contributions, whilst also presenting some concrete examples of changes - inter alia — in the macroeconomic, political and banking context that may help to explain the past decade of reforms.

To end, we reflect briefly on what the past decade of post-crisis financial regulatory reform tells us about the likely trajectory of bank influence in the future. As European economies have slowly recovered and collective memories of the financial and sovereign debt crises gradually recede, a business power account might reasonably expect the power of the financial industry to increase. Indeed, as the salience of financial regulation declines, so we might predict the return of a "quiet politics" of bank power, heralding a swing in the regulatory pendulum back to a lighter touch approach. Indeed, a number of top bank supervisory officials have warned loudly of such a development. ${ }^{82}$ However, we argue that there are at least two grounds for disputing this prediction. First, in political terms, the end of the financial crisis has not produced a return to pre-crisis normality or predictability. On the contrary, growing dissatisfaction with the economic status quo in an era of stagnant wages and inflated asset prices has translated into mounting political distrust

\footnotetext{
${ }^{81}$ Macartney and Calcagno (2019).

${ }^{82}$ Financial Times (2017); Financial Times (2019).
} 
and voter anger. As a result, electorates have become increasingly polarised and election outcomes have become increasingly volatile - particularly in those countries that experienced the greatest economic turmoil over the past decade. Hence, far from heralding a return to the "quiet politics" of bank influence, we have seen the financial industry repeatedly buffeted by an increasingly "noisy" post-crisis politics.

Second, this new politics has witnessed the rise of "populist" parties, leaders and policies notably in the form of President Trump in the US and the Brexit referendum vote in the UK. Intriguingly, despite both political developments occurring at a time when the centre-right is in power, the implications for the banking sector have been decidedly mixed. On the one hand, Trump's election has paved the way for a significant rolling back of the Dodd-Frank financial regulatory reforms, particularly with regard to the implementation and applicability of the Volcker Rule. Yet Wall Street remains nervous about the unpredictability of the Trump administration, particularly with respect to its attempt to clamp down on the US financial industry's links with China. ${ }^{83}$ On the other hand, Brexit risks seriously undermining the City of London's status as Europe's largest international financial centre by erecting new barriers to financial services trade between the UK and the EU. ${ }^{84}$ Surprisingly, from a business power perspective, the UK government has sought to prioritise the political imperative of withdrawing from the EU single market over the immediate economic concerns - and extensive lobbying — of its own financial industry. ${ }^{85}$ On balance then, the implications of heightened economic uncertainty and political instability in this post-crisis period are unpredictable for the banking industry. This points to the importance of continuing to refine and develop new theories and analytical perspectives on bank power in an era of "hyper-politics": an intellectual endeavour to which this special issue aims to make an important contribution.

\section{References}

Acharya, V, D. Anginer, and A. J. Warburton. 2014. "The end of market discipline? Investor expectations of implicit government guarantees." https://papers.ssrn.com/sol3/papers.cfm?abstract_id=1961656

Alessandri, P. and A. Haldane. 2009. "Banking on the state." Paper by Mr Andrew G Haldane, Executive Director, Financial Stability, Bank of England, and Mr Piergiorgio Alessandri, based on a presentation delivered at the Federal Reserve Bank of Chicago twelfth annual International Banking Conference on “The International Financial Crisis: Have the Rules of Finance Changed?", Chicago, 25 September 2009.

Andrés, P. de, R. Reig, and E. Vallelado. 2018. "European Bank's Executive Remuneration Under the New European Banking Regulation.” Journal of Economic Policy Reform 22 (3): 208-225.

\footnotetext{
${ }^{83}$ Politico (2019).

${ }^{84}$ Howarth and Quaglia (2018).

${ }^{85}$ James and Quaglia $(2019,2020)$.
} 
Andrews, D. 1994. "Capital Mobility and State Autonomy: Toward a Structural Theory of International Monetary Relations.” International Studies Quarterly, 38(2): 193-218.

Balasubramnian, B. and K. B. Cyree. 2011. "Market discipline of banks: why are yield spreads on bank-issued subordinated notes and debentures not sensitive to bank risks?" Journal of Banking and Finance 35: 21-35.

Barclays. 2009. Annual Report 2009.

Barth, J., G. J. Caprio, and R. Levine. 2012. Guardians of Finance: Making Regulators Workfor Us. Cambridge: MIT Press.

Bell and Hindmoor. 2015. "Masters of the Universe but Slaves of the Market: Bankers and the Great Financial Meltdown.” British Journal of Politics and International Relations 17(1): 1-22.

Bell and Hindmoor. 2017. "Structural Power and the Politics of Bank Capital Regulation in the United Kingdom.” Political Studies, 65(1): 103-121.

Bernhagen, P. 2007. The Political Power of Business. London: Routledge

Blinder, A., and M. Zandi. 2010. "How the Great Recession Was Brought to an End". https://www.economy.com/mark-zandi/documents/End-of-Great-Recession.pdf

Block, F. 1987. "State Theory in Context." In Revisiting State Theory, edited by F. Block. Philadelphia: Temple University Press, 3-35.

Blyth, M. 2002. Great Transformations: economic ideas and institutional change in the twentieth century. Cambridge: Cambridge University Press.

Bonefeld, W. 2017. The Strong State and the Free Economy. London: Rowman and Littlefield.

Brittan, S. 1989. “The 'Economic Contradictions of Democracy' Revisited." Political Quarterly 60(2): 190-203.

Burnham, P. 2011. "Towards a political theory of crisis.” New Political Science 33(4): 493-507.

Campbell-Verduyn, M. 2017. "Capturing the Moment? Crisis, Market Accountability, and the Limits of Legitimation.” New Political Science 39(3): 350-368.

Chalmers, A. and K. Young. 2020. “..” Business and Politics 22(1): XX-XX.

Citigroup. 2008. Annual Report.

Coban, M. 2020. "Select Compliance forces, domestic policy process, and international regulatory standards: Compliance with Basel III." Business and Politics 22(1): XX-XX. 
Coen, D. and J.-P. Salter. 2020. "Multilevel regulatory governance: Establishing bank-regulatory relationships at the European Banking Authority." Business and Politics 22(1): XX-XX.

Cohan, W.D. 2011. Money and Power: How Goldman Sachs Came to Rule the World. London: Allen Lane.

Claessens, S., Underhill, G.R.D, Zhang, X. (2008), 'The political economy of Basle II: the costs for poor countries', The World Economy: 313-43.

Culpepper, P. 2012. Quiet Politics and Business Power. Cambridge: Cambridge University Press.

Culpepper, P. 2015. "Structural Power and Political Science in the Post-Crisis Era." Business and Politics 17:3, October 2015, pp. 391-409.

Culpepper, P., and R. Reinke. 2014. "Structural Power and Bank Bailouts in the United Kingdom and the United States.", Politics \& Society 42(2): 427-454.

Dahl, R.A., and C. E. Lindblom. 1976. Politics, Markets and Welfare. Chicago: University of Chicago.

Emmenegger, P. 2015. "The long arm of justice: U.S. structural power and international banking." Business and Politics 17(3): 473-493.

Engelen, E., I. Ertürk, J. Froud, S. Johal, A. Leaver, M. Moran, A. Nilsson, and K. Williams. 2012. After the Great Complacence: Financial Crisis and the Politics of Reform. Oxford: Oxford University Press.

FDIC (Federal Deposit Insurance Corporation). 1987. Mandate for Change: Restructuring the Banking Industry. 112, Washington: Federal Deposit Insurance Corporation.

Financial Times. 2016. "UK facing 'dreadful' wage stagnation: 3 charts from the IFS." 24 November.

Financial Times. 2017. “BoE official warns of return to 'light touch' regulation.” 26 February.

Financial Times. 2018. "How US banks took over the financial world.” 17 September.

Financial Times. 2019. "German bank supervisor warns of a new cycle of deregulation." 19 October.

Gamble, A. 2009. The Spectre at the Feast. Basingstoke: Palgrave.

Ganderson, J. 2020. "To Change Banks or Bankers? Systemic Political (In)action and Post-Crisis Banking Reform in the UK and the Netherlands." Business and Politics 22(1): XX-XX.

Garrett, B. 2016. “The Rise of Bank Prosecutions.” Yale Law Review Forum 126(33). 
Haldane, A., M. Roberts-Sklar, T. Wiedladek, C. Young. 2016. "QE: the story so far." Bank of England Working Paper 624, 19 October; https://www.bankofengland.co.uk/workingpaper/2016/qe-the-story-so-far

Hall, P. 1986. Governing the Economy. Oxford: Oxford University Press.

Hau, H., S. Langfield, and D. Marques-Ibanez. 2013. "Bank Ratings: What Determines Their Quality?" Economic Policy 28(74) (April): 289-333.

Hay, C., and B. Rosamond. 2002. "Globalization, European integration, and the discursive construction of economic imperatives." Journal of European Public Policy 9(2): 147-167.

Helleiner, E., and S. Pagliari. 2011. "The End of an Era in International Financial Regulation? A Post-Crisis Research Agenda.” International Organization 65: 169-200.

Helleiner, E., Pagliari, S., and Zimmerman, H. (eds.) (2010) Global Finance in Crisis: The Politics of International Regulatory Change. London: Routledge.

Howarth, D., and S. James. 2020. "The politics of bank structural reform:

Business power and agenda setting in the United Kingdom, France, and Germany." Business and Politics 22(1): XX-XX.

Howarth, D., and L. Quaglia. 2013. "Banking on Stability: the European Union's New Capital Requirement Directive.” Journal of European Integration 35(3): 333-346.

Howarth, D., and L. Quaglia. 2016. "The Comparative Political Economy of Basel III in Europe." Policy and Society, 35: 205-214.

Howarth, D. and Quaglia, L. 2018. "Brexit and the battle for finance." Journal of European Public Policy 25 (8): 1118-36.

Ingham, G. 1984. Capitalism divided?: the City and industry in British social development. London: Macmillan.

James, S. 2018. "The Structural-Informational Power of Business: Credibility, Signalling and the UK Banking Reform Process”. Journal of European Public Policy 25(11): 1629-47.

James, S. and Christopoulos, D. 2018. "Reputational leadership and preference similarity: Explaining organisational collaboration in bank policy networks". European Journal of Political Research 57 (2): 518-38.

James, S. and Quaglia, L. 2019. "Brexit, the City and the Contingent Power of Finance." New Political Economy 24 (2): 258-271. 
James, S., and Quaglia, L. 2020. The UK and Multi-Level Financial Regulation: From Post-Crisis Reform to Brexit. Oxford: Oxford University Press.

Jimeno, J. 2015. "Long-lasting consequences of the European crisis.” ECB Working Paper Series, No. 1832, July, https://www.ecb.europa.eu/pub/pdf/scpwps/ecbwp1832.en.pdf

Johnson, S., and J. Kwak. 2010. 13 Bankers: The Wall Street Takeover and the Next Financial Meltdown. New York: Vintage Books

Levine, M. 2017. "Dog leasing and bank fines.” https://www.bloomberg.com/view/articles/201703-02/dog-leasing-and-bank-fines

Lindblom, C. E. 1977. Politics and Markets. New York: Basic Books.

Lindblom, C. E. 1982. “The market as prison.” The Journal of Politics 44(2): 324-336.

Lindh, S. and S. Schich. 2012. "Implicit Guarantees for Bank Debt: Where Do We Stand?" OECD Journal of Financial Market Trends 1 (June): 45-63.

Macartney, H. 2014. "From Merlin to Oz: the strange case of failed SME lending targets in the UK." Review of International Political Economy 21(4): 820-46.

Macartney, H. 2019. The Bank Culture Debate: ethics, values and financialisation in AngloAmerica. Oxford: Oxford University Press.

Macartney, H., and P. Calcagno. 2019. All Bark and No Bite: the political economy of bank fines in Anglo-America, Review of International Political Economy.

Marsh, D., and C. Lewis. 2014. "The Political Power of Big Business: A Response to Bell and Hindmoor." New Political Economy 19(4): 628-633.

Massoc, E. 2020. "Banks, power, and political institutions: the divergent priorities of European states towards 'too-big-to-fail' banks: The cases of competition in retail banking and the banking structural reform." Business and Politics 22(1): XX-XX.

McKeen-Edwards, H. and Porter, T. 2013. Transnational Financial Associations and the Governance of Global Finance. London: Routledge.

McKinsey. 2016. A Best Practice Model for Bank Compliance, January 2016. McKinsey \& Company.

Miller, G. P. 2017. The Law of Governance, Risk Management, and Compliance. New York: Wolters Kluwer.

Montalbano, G. 2020. "Policy entrepreneurship and the influence of the transnational financial industry in the EU reform of securitization." Business and Politics 22(1): XX-XX. 
Moran, M. 2009. Business, Politics, and Society: an Anglo-American Comparison. Oxford University Press.

Morgan, D., and K. Stiroh. 2005. "Too big to fail after all these years." Federal Reserve Bank of New York Staff Report No. 220.

Mügge, D. 2010. Widen the Market, Narrow the Competition: Banker Interests and the Making of a European Capital Market. Colchester: ECPR.

Müller-Armack, A. 1978. "The Social Market Economy as an Economic and Social Order." Review of Social Economy 36(3): 325-31.

Nettl, J. P. 1965. "Consensus or elite domination: the case of business." Political Studies 13: 2244 .

New York Times. 2018. “Congress Approves First Big Dodd-Frank Rollback.” 22 May.

Newman, A. and Posner, E. 2018. Voluntary Disruptions: International Soft Law, Finance, and Power. Oxford: Oxford University Press.

OCC. 2016. "Survey of Credit Underwriting Practices." Office of the Comptroller of the Currency, Washington DC.

Offe, C. 1974 "Structural problems of the capitalist state: class rule and the political system: On the selectiveness of political institutions", German Political Studies, 1: 31-54.

O'Hara, M. and Shaw, W. 1990. "Deposit insurance and wealth effects: The value of being 'too big to fail"." Journal of Finance 45: 1587-1600.

Pagliari, S., and Young, K.L. 2014. "Leveraged Interests. Financial Industry Power and the Role of Private Sector Coalitions.” Review of International Political Economy 21(3): 575-610.

PIMCO. 2018. "Investing in a Negative Interest Rate World." Investment Education. Newport Beach, CA: PIMCO; https://global.pimco.com/en-gbl/resources/education/investing-in-anegative-interest-rate-world.

Politico 2019. "Trump administration considers hitting China's Wall Street connections." 27 September.

PWC 2009. "Bringing back best practices in risk management: banks' three lines of defense", PWC, https://www.strategyand.pwc.com/media/file/Bringing-back-best-practices-banks-threelines-of-defense.pdf

Quaglia, L., and Howarth, D. 2018. "The policy narratives of European capital markets union.” Journal of European Public Policy 25(7): 990-1009. 
Quinn, D.P., and R.Y. Shapiro. 1991. "Business political power: The case of taxation.” American Political Science Review 85: 851-874.

Przeworksi, A., and E. Wallerstein. 1988. "Structural Dependence of the State on Capital." American Political Science Review 82(1): 11-29.

Seabrooke, L., and E. Tsingou. 2009. "Revolving doors and linked ecologies in the world economy: policy locations and the practice of international financial reform." Centre for the Study of Globalisation and Regionalisation, Department of Politics and International Studies, University of Warwick, CSGR Working Paper; https://warwick.ac.uk/fac/soc/pais/research/researchcentres/csgr/papers/workingpapers/2009/260 09.pdf

Skidelsky, R. 2009. Keynes: The Return of the Master, London: Allen Lane.

Smith, M. J. 2009. Power and the State. Basingstoke: Macmillan.

Stellinga, B. 2020. “The open-endedness of macroprudential policy. Endogenous risks as an obstacle to countercyclical financial regulation." Business and Politics 22(1): XX-XX.

Stellinga, B. and Mügge, D. 2017. “The regulator's conundrum. How market reflexivity limits fundamental financial reform." Review of International Political Economy. 24 (3): 393-423.

Stern, G. H., and R. J. Feldman. 2004. Too Big To Fail: the Hazards of Bank Bailouts. Washington: Brooking Institute Press.

Stigler, G. J. (1971), 'Theory of economic regulation', Bell Journal of Economics and Management Science 2 (1): 3-21.

Strange, S. 1998. Mad Money: When Markets Outgrow Governments. Ann Arbor: University of Michigan Press.

Streeck, W. 2014. Buying Time: the delayed crisis of democratic capitalism, Verso.

Swank, D. 1992. "Politics and the structural dependence of the state in democratic capitalist nations." American Political Science 86(1): 38-54

Tsingou, E. 2015. "Club Governance and the Making of Global Financial Rules." Review of International Political Economy 22(2): 225-256.

Turner, D. and Ollivaud, P. 2019. "The output cost of the global financial crisis: A reappraisal after ten years." SUERF Policy Note 53; https://www.suerf.org/policynotes/4213/the-output-cost-ofthe-global-financial-crisis-a-reappraisal-after-ten-years/html

van Apeldoorn, B. 2002. Transnational Capitalism and the Struggle over European Integration, London: Routledge. 
Vogel, D. 1989. Fluctuating Fortunes. New York: Basic Books.

Vogel, D. 1996. Kindred Strangers. Princeton: Princeton University Press.

Wall Street Journal (2017) "Regulators Drop Pursuit of Banker, CEO Pay Restrictions.” 20 July.

Wolf, M. (2008), 'Why financial regulation is both difficult and essential', Financial Times, 15 April.

Wolf, M. (2012), 'This global financial fraud and its gatekeepers', The Guardian, 14 July.

Woll, C. 2014. The Power of Inaction: bank bailouts in comparison. Ithica: Cornell University Press.

Young, K. and Pagliari, S. (2017). "Capital United? Business unity in regulatory politics and the special place of finance.” Regulation \& Governance 11(1): 3-23.

Ziegler, N. and Woolley, J. 2016. "After Dodd-Frank: The post-enactment politics of financial reform in the United States." Politics and Society 44 (2): 249-80. 